Asian Development Policy Review

$\operatorname{ISSN}(e): 2313-8343$

$\operatorname{ISSN}(p): 2518-2544$

DOI: 10.18488/journal.107.2021.94.180.193

Vol. 9, No. 4, 180-193.

(C) 2021 AESS Publications. All Rights Reserved.

URL: www.aessweb.com

\title{
EXAMINATION OF THE CAUSES AND CONSEQUENCES OF
INTERNATIONAL MIGRATION IN NIGERIA
}

Innocent.U. Duru Department of Economics, Renaissance University, Ugbawka, Enugu State, Nigeria.

Email:uchechukwuduru1@gmail.com Tel:+234-8065347908

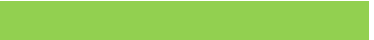

Article History

Received: 4 August 2021 Revised: 1 September 2021 Accepted: 20 September 2021 Published: 13 October 2021

\section{Keywords}

International migration

Push

Pull methodological framework Migrants

Causes

Consequences

Nigeria.

JEL Classification: F22; J11; O 15; O55.

\section{ABSTRACT}

This study examined the leading causes and consequences of international migration in Nigeria. A survey research design was utilized for the study. The data was collected through a structured questionnaire. The opinions of 100 respondents selected through the purposive sampling technique were obtained on the principal causes and consequences of international migration in Nigeria. The findings revealed that the principal causes of international migration in Nigeria were job opportunities, unemployment, wealth prospects, safety and security, better conditions of service, low salaries and higher standards of living. These foremost causes of international migration in Nigeria were mostly economic factors. Furthermore, the findings showed that the foremost positive and negative effects of international migration in Nigeria were integrated development, increase in remittances, cheap and surplus labour, urban services and social infrastructure under stress, stricter immigration norms, multi-ethnic society and increased tolerance, Xenophobia, close gaps in skills and cultural dilution. These effects were economic, social and political. Among others, the study, thus, recommends that: the strategies of the government for stemming international migration should address push factors of unemployment, safety and security and low salaries and pull factors such as job opportunities, wealth prospects, better conditions of service and higher standards of living since they are the root causes of international migration. Furthermore, migration, a long-standing poverty reduction and strategy for human development need to be mainstreamed into policies of development in Nigeria at the Federal, State and Local Governments.

Contribution/ Originality: This study contributes to existing literature by examining the leading causes and consequences of international migration in Nigeria. The outstanding contribution of this study is that it examined numerous push and pull factors that are economic, sociopolitical and ecological that could motivate Nigerians to migrate.

\section{INTRODUCTION}

The migration of human beings is not a new event. Migration has been part of the existence of man since the chronicle of man. The phenomenon of migration dates back to the mercantile era where roughly 1500 to 1800 European migrants through merchant capitalism travelled to Africa to acquire protectorates and inhabit enormous pieces of land for more than 300 years (Golden \& Reinert, 2006). Furthermore, the National Geographic Society (2005) stated that migration occurred all through the history of man, starting with the movements of the first 
groups of humans in East Africa to their present locality in the universe. The magnitude of migration in the universe has made it the main policy concern of nearly every country in developing and developed economies.

The international organization for migration (IOM) stated that migration can be defined as:

A process of moving, either across an international border or within a State. It is a population movement, encompassing any kind of movement of people, whatever its length, composition and causes; it includes migration of refugees, displaced persons, uprooted people, and economic migrants (IOM, 2004).

Furthermore, migration is a reaction to a crisis that has economic, political and socio-cultural dimensions by persons, either individually or as a group to enable them to survive the situation. Advanced economies of the world are the main targets of international migrants. In the views of Rohrmoser and Wachter (2008), the flows of migration in the globe today were influenced by colonial bonds between Europeans and Africans. Also, a high rate of unemployment, lack of social amenities, poverty, economic crisis, political instability, insecurity, poor wages and other unfavourable conditions account for external migration in most economies in the universe. Because of the failure of the Nigerian labour market to provide jobs for youths, they are left with no option than to migrate. External migration has implications with economic, socio-cultural and political dimensions for economies of the developing and developed world.

For instance, some of the international migrants had to cope with the restrictive policies on immigration instituted by governments of top countries of destinations to handle the challenges of external migration. Furthermore, most of these immigrants have lost their rights to health care, movement, employment, education, among others as a result of improper documentation. Again, some migrants may resort to deviant lifestyles to make ends meet. Yang (2008) stated that armed robbery, increasing crime rate, prostitution and pickpocketing are among these inappropriate lifestyles. Some of the jobs that result from these lifestyles are considered “3D jobs”. These are difficult, dirty and dangerous jobs. Because of these challenges, the economic, political and social reasons for migration are in most cases defeated.

Statistical evidence from the World Migration Report of 2020 revealed that the number of international migrants worldwide was 272 million in 2019 (McAuliffe \& Khadria, 2019). This represents 3.5 per cent of the population of the globe. In addition, in terms of gender, 52 per cent and 48 per cent of international migrants were male and female respectively. Also, the number of international migrants in the working-age of 20 to 64 years was 74 per cent. Furthermore, India was the leading country of origin of international migrants with 17.5 million migrants. Mexico and China are in second and third positions with 11.8 million and 10.7 million international migrants respectively.

However, United States remained the leading country of destination for international migrants with 50.7 million international migrants. Again, the IOM opined that since 2014, more than 600 000 migrants from Africa travelled to Italy through the dangerous route of the Central Mediterranean (Kirwin \& Anderson, 2018). However, almost 120000 African migrants reached Italy in 2017 alone. No wonder, Ranjana (2015) observed that "It has become a serious issue of the twenty-first century because of rapid globalisation, industrialization, urbanization and related migration patterns which are forcing people to move from one place to another in search of livelihood options and employment opportunities" (p.2). However, Abedi-Lartey (2016) observed that:

Migration has been identified as a survival strategy utilised by the poor, especially the rural folks as a catalyst in the transformation process of not only the destiny of individual migrants, but also, the conditions of family members left behind, local communities, and the wider regions through remittances. (p.3)

Hence, the examination of the causes and consequences of international migration in Nigeria was informed by the need to fathom the possible push and pull factors responsible for the high rate of external migration in the country. Fathoming the core causes of international migration and portraying the multifaceted effects of external migration in Nigeria will inform policy decisions on this issue and provide insights on the proper choice of development strategies for the economy. Despite the innumerable efforts of the Federal, State and Local 
governments, Non-Governmental Organizations (NGOs) and other stakeholders to stem the unending tide of migration in Nigeria, the phenomenon has continued unabated. Despite the challenges of international migration, citizens of Nigeria have continued to migrate to economies of the world with economic stability to find economic opportunities to sustain themselves and their dependents at home. Low-intensity conflict, inadequate economic opportunities and a large youth population had combined and resulted in a great number of irregular migrants striving to embark on the dangerous trip to Europe from Nigeria. No wonder, IOM (2016) stated that migration is characterized by a series of economic, social, political and cultural consequences.

Against this background, this study plans to investigate the leading causes of international migration along with the principal effects of international migration in the context of Nigeria. The questions that will be addressed in this study are: what are the top factors causing external migration in Nigeria? What are the topmost effects of external migration in Nigeria? The core objective of this study is to examine the leading causes of external migration in Nigeria. Furthermore, the study will investigate the leading consequences of international migration in Nigeria.

The rest of the paper is structured as follows: section two will focus on literature review and theoretical framework, the methodology is considered in section three. Presentation of data, analysis and discussion of results will be the focus of section four while the conclusion and recommendations are examined in section five.

\section{LITERATURE REVIEW AND THEORETICAL FRAMEWORK}

\subsection{Literature Review}

The causes and consequences of external migration have been investigated by various scholars with different outcomes and abstractions. For instance, De Haas (2007) through a review of existing literature, examined the effect of international migration on the social and economic development of regions that send migrants to Morocco. Evidence from these empirical studies indicates that education, living conditions and income have improved significantly as a result of migration and remittances. Also, owing to agriculture, investment in businesses and real estate, economic activity has been encouraged and it indirectly benefits non-migrants. Furthermore, regions like the Rif, Sous and Southern oases that send migrants have changed to prosperous areas attracting internal 'reverse' migrants. Owing to numerous structural restrictions, the developing potential of migration was not completely attained. Again, the effect of migration was heterogeneous across socio-ethnic, gender groups and the universe and inclined to change from time to time. Through migration and remittances, people may invest in economic activities locally. Unexpectedly, to a certain extent, development in regions that send migrants appears to be a condition for homecoming and investment than an aftermath of migration.

Similarly, Ratha, Mohapatra, and Scheja (2011) embarked on a literature survey of the impact of migration on economic and social development on countries of origin and destinations in the South. The review showed that International migration had critical development effects in sending and receiving economies. Also, migration and the resultant remittances result in increased incomes, reduction of poverty, improved health, better educational outcomes and boost economic development in sending economies. However, considerable social costs that are inevitable for the migrants and their families may be involved in the realization of these gains. Numerous developing economies encounter challenges such as the integration of immigrants, fiscal costs related to the provision of social services to the migrants and job competition between migrant and native workers because they receive substantial international migrants.

In another related research, Adepoju (2011) considered the relationship between international migration and development in Sub-Saharan Africa. The study revealed that poverty, unstable polity and fast growth of the population are the driving force of migration. In terms of the development of Sub-Saharan African countries, rising remittances serve as a critical source of income and lifeline for the payment of basic services, education fees, health 
care and enhancement of production in agriculture. Retaining, attracting and efficiently utilizing the unique skills of these nationals in diaspora for indigenous development is the main challenge of Sub-Saharan African economies.

Furthermore, Weda (2012) employed the qualitative research approach to investigate the factors affecting the migration of teachers from Zimbabwe to South Africa. The study used documented information from prevailing literature, 13 Zimbabwean teachers that have been living in South Africa from one year to five years and a grounded theory. The collection of data were in two phases: in phase one, the participants were requested to deliver verbally or put in writing their migration experiences in South Africa. In phase two, they were interviewed to explain the issues solicited in phase one. The grounded theory of teachers' migration was generated after three stages of coding employed in data analysis. These are the initial, intermediate and advanced stages. The findings showed that the emigration of teachers from Zimbabwe to South Africa was based on teachers attaining and maintaining the best or an ideal living standard, conditions of work and social prestige. The substantive theory sees the combination of these interrelated factors in their ideal shape as the Ideal Status. This status is considered ideal by the sampled teachers. Furthermore, the grounded theory showed that the best way to realize an ideal status from the point of view of teachers from Zimbabwe was migration.

In Nigeria, Ajaero and Onokala (2013) in related literature examined the relationship between rural-urban migration and the rural communities of South-Eastern Nigeria. Based on the size of the population and spatial equity, six Local Government Areas (LGAs) in the rural areas were chosen from two states of South-Eastern Nigeria. These states were Imo and Abia States. The LGAs were Ikwuano in Abia State, Isikwuato in Abia State, Ukwa East in Abia State, Nkwerre in Imo State, Onuimo in Imo State and Owerri West in Imo State. Fifty households that send migrants were sampled from each of the six LGAs in the rural areas. Employing multiple regression methodology, Chi-square, hierarchical cluster analyses and a mixed-methods approach for the collection of data, the results revealed that rural-urban migration adds meaningfully to the development of the rural communities in South-Eastern Nigeria through remittances and the participation of these rural-urban migrants in the development projects in the community.

Likewise, Anjofui (2018) examined the push and pull factors of international migration in South Africa focusing on the Cameroonian and Congolese migrants in Cape Town. The Cameroonian and Congolese migrants in Cape Town were selected through the snowball sampling technique. Employing a descriptive research design through semi-structured interviews, the results revealed that the main drivers of migration are economic factors. This is followed by the influence of migrant networks and political factors respectively. Through most of the migrants', aspirations and exposure factor was discovered to be among the factors influencing migration decisions. However, they were not pinpointed in the literature as factors affecting migration. Furthermore, the results showed that the migration expectations of most of the migrants were not met. This is as a result of limited opportunities presented to them due to policies of migration. Also, the current policy on migration has affected migrants negatively, reducing them to a miserable state. However, since the goals of migration have not been met, most migrants chose not to return home.

Relying on public opinion and focus group data obtained in West Africa through a descriptive research design, Kirwin and Anderson (2018) investigated the factors that cause West Africans to migrate. Also, the study directed attention to Nigeria, the country of origin for twenty-five per cent of all migrants from Africa travelling through the Central Mediterranean route. Respondents were drawn from six West African countries of Burkina Faso, Cote d' Ivoire, Mali, Niger, Nigeria and Senegal. Economic factors were identified as the rationale for migration. However, family and patriotism were observed as reasons for respondents to desire to remain in their own countries. Evidence from the survey revealed that 50 per cent, 27 per cent and 27 per cent of Nigerians, Ivoirians and Senegalese respectively were interested in departing their countries of origin if given the opportunity. However, the number of Malians and Burkinabe that were also interested in emigrating if given the opportunity were less compared to Nigerians, Ivoirians and Senegalese. Furthermore, the findings showed that the class of 
Nigerians that were very likely to travel abroad are the urban and highly educated ones. From the role of religion in migration, Nigerian Muslims are less expected to desire to migrate abroad. In addition, the economic position did not exert a meaningful influence on the desire of Nigerians' to migrate. Instead, the views of individuals on the strength of democracy in Nigeria are very strongly related to the desire of Nigerians' to migrate abroad, followed by inadequate trust in indigenous security.

Using data from a household survey on migration and remittance conducted by World Bank, Bedasso, Weldesenbet, and Obikili (2018) in another similar study investigated the effect of family migration on the attainment of education. The results showed that members belonging to the household of migrants have a higher likelihood of finishing secondary education and going to some post-secondary schools. Again, members of migrant households have a higher likelihood of emigration. Furthermore, the attainment of education could be realized through the migration of members of the migrants' families.

Dimkpa (2019) used a qualitative research design, four migrants from Nigeria that has travelled to Europe through the Libya-Mediterranean route and the Push and Pull methodological framework developed by Everett Lee to investigate the migration account of Nigerians that went to Europe through the Libya-Mediterranean route and stopped in Sweden. Based on the Push and Pull model of Everett Lee, this study specified the reasons why migrants from Nigeria travel to Europe through the Libya-Mediterranean route, how they ended up in Sweden, and their decision to seek asylum in Sweden rather than other economies in Europe. Also, the Swedish policy on migration and asylum as regards migrants from Nigeria was discussed. The findings revealed that insecurity, political instability, terrorism, economic crisis, and stringent laws against homosexuality are the factors that could motivate Nigerians to travel to Europe for a better life through the Libya-Mediterranean route.

Evidence from the prevailing literature on migration demonstrated that no studies have been done to the best of our knowledge in the developed countries to fathom the causes and consequences of international migration. However, the number of such studies is limited in Africa and specifically very scarce in Nigeria. Few of the past studies dwelt on the economic, political and socio-cultural factors that result in human trafficking, which is a form of migration. Another study by Oludayo (2019) focused on child trafficking. The study by Nwalutu (2016) dwelt on the migration experiences of Nigerian migrant youth in Malta. However, Oyebanji (2017) focused on the experiences of young women that survived trafficking in Nigeria. Bakke (2013) looked at how religion influences trafficking in Nigerian women. Ajaero and Onokala (2013); Olajide (2014) and Bukar, Mohammed, and Ngada (2021) studied internal migration in the context of rural-urban migration. Wajim (2019) focused on the causes and patterns of labour migration in Nigeria. Adebowale (2014) focused on industrialization, entrepreneurship and the cyclical migration flows between Ghana and Nigeria. Ozuru and Nwajah (2019) dwelt on the human rights approach for the treatment of migrants in Nigeria. In another study, Muhammad (2021) investigated the subject of irregular migration and its consequences on security challenges in North-Western Nigeria. Enigbokan, Edkins, and Ogundele (2015) looked at the importance of theories of migration in the identification of motivating factors for migrants from Nigeria and Zimbabwe in South Africa. To the best of our knowledge, there was no study directly on the causes and consequences of international migration in Nigeria. Again, facts on how individuals balance the dangers and gains of international migration, and how it affects their decisions to emigrate is little in Nigeria. Thus, this study intends to bridge this gap by carrying out an in-depth examination of the push and pull factors of international migration along with the consequences of this issue in the Nigerian context.

\subsection{Theoretical Framework}

Scholars in the various disciplines that research on migration such as economics, law, demography, history, geography, sociology, anthropology, political science, among others in an attempt to unravel the causes, effects and dynamics of migration have spawned a wide variety of theories. These theories are Lee (1966) theory of migration, Harris and Todaro (1970) neo-classical migration theory, Mabogunje (1970) migration systems theory, Zelinsky 
(1971) mobility transition theory, Stark (1978); Stark (1991) new economics theory of migration, Piore (1979) dual labour-market theory, Skeldon (1990) work on migration transitions, Massey (1990) cumulative causation theory among others. The push and pull methodological framework of the neoclassical economic theory by Everett Lee was used as the theoretical platform for this study.

This is based on the premise that the current overriding theory in the investigation of the causes of migration is the neoclassical theory with the fundamental assumption that the main motivation for migration is economic deliberations of comparative benefits and costs, largely financial and psychological borne out of rational decisions Todaro and Smith (2006). Hence, it will be used in this study to know the migration decisions of international migrants. Because this theory sees migration as an economic phenomenon, it contends that economic factors are the main driving force of migration (Nkamleu \& Fox, 2006). Furthermore, it presupposes that trade and migration serve as a platform for labour markets and economies to move near a long-run steady state. It believes that migrants are just rational actors. Under this theory, an abundance of labour and low wages in a society results in movements of migrants to societies of scarce labour and high wages. Also, the choice of migration is taken individually. Hence, in a nutshell, migrants move from societies of a large labour force and low wages to societies of a small labour force and high wages. Meanwhile, the feeling that higher returns expected at the end would offset the cost and relocation risk further informs the decision to migrate.

The push and pull methodological framework submits that the low wages and poor standards of living in less developed countries push away the labour force whereas high salaries and better standards of living in the more industrialised regions pull them in Harzig, Hoerder, and Gabaccia (2009). Under the push and pull factor model, the exodus of individuals from an area with low labour demands and low salaries to one with high labour demand and high salaries is expected to finally align the salaries and conditions of living between the sending and receiving regions so that migration would be beneficial to both (Nkamleu \& Fox, 2006; Weiner, 1995). The emigration of workforces in a given area decreases the supply of labour in the labour market in the locality and enlarges its value causing higher salaries. Thus, the emigration of labours from an area is beneficial for workers at home since it leads to an increase in wages locally (Weda, 2012).

The push and pull model has some limitations. It is a static model. Thus, it failed to state how original structural conditions are influenced by migration. It is a descriptive model that employs a post-hoc mechanism in the explanation of migration. Again, factors that influence migration are usually copied in origin and destination areas. It believes that macro-level variables are the only causes of migration. However, it ignores other motives of individuals for migration. Despite these shortcomings, the theory is still fashionable in the literature of migration (De Haas, 2007; McDowell \& De Haan, 1997). However, it was modified to incorporate some added pull and push factors. Dovlo (2003) stated that the push factors or supply factors are the conditions that are unfriendly in the source countries or regions that make professionals and skilled workers emigrate and search for employment elsewhere. The literature pinpointed the following push factors: low salaries; low per capita income; unemployment or job scarcity; crime and conflict; political repression; poor educational systems; poor conditions of service; climate change (including extreme weather events); lack of progression within a career; inadequate or limited urban services and infrastructure (including healthcare, education, utilities, transport and water); lack of necessary technology; crop failure and scarcity of food; safety and security concerns (ethnic, religious, racial or cultural persecution); rural poverty; political instability; slavery or bonded labour; unsustainable livelihood and resources and limited chances of self-advancement (Boswell, 2002; Dovlo, 2003; El-Khawas, 2004; World Economic Forum \& PwC, 2017).

Pull factors or demand factors are the socio-economic settings that entice professionals to leave their countries of origin or regions to destination economies or regions (El-Khawas, 2004). The following pull factors have been spotted in the literature: higher salaries for the same jobs in the receiving countries; family reunification; better conditions of services; independence and freedom; advanced technology and availability of resources that make work easier and safer; integration and social cohesion; the situation of the labour market in receiving countries; food 
security; higher chances of professional and personal improvement; affordable and accessible urban services (comprising healthcare, education, utilities and transport); greater environmental safety; higher standards of living; abundance of natural resources and minerals (e.g. water, oil, uranium); legislation on migration; pursuit of specialized education, favourable climate and less bureaucratic control (Boswell, 2002; El-Khawas, 2004; World Economic Forum \& PwC, 2017).

\section{METHODOLOGY}

The descriptive research design was utilized for this study. The study employed primary and secondary sources of data collection. First-hand information was obtained through a structured questionnaire. On the other hand, information that was already existing on international migration in books, the internet, reports, journal articles and other relevant sources constituted the secondary data. The judgmental or purposive sampling technique was used for this study. One hundred respondents in Nigeria were purposively selected for this study. They were selected based on the researcher's belief that they will meet the requirements of the study. Hence, these respondents were selected based on the researcher's judgement that they were not only equipped with the knowledge of external migration but understands what represents push and pull occurrence. Questionnaires were administered to respondents to obtain their opinions on the causes and consequences of external migration in Nigeria. The Statistical Package for Social Sciences (SPSS) was utilized for data analysis. The collected data were analysed with descriptive statistics.

Table-1. Demographic characteristics of respondents.

\begin{tabular}{|c|c|c|c|}
\hline Variable & Items & Frequency & Percentage (\%) \\
\hline Age & $\begin{array}{l}\text { Less than } 20 \text { years } \\
21-30 \text { years } \\
31-40 \text { years } \\
41-50 \text { years } \\
51-60 \text { years } \\
61 \text { years and above } \\
\text { Total }\end{array}$ & $\begin{array}{c}11 \\
32 \\
30 \\
17 \\
8 \\
2 \\
100\end{array}$ & $\begin{array}{c}11.0 \\
32.0 \\
30.0 \\
17.0 \\
8.0 \\
2.0 \\
100.0\end{array}$ \\
\hline Gender & $\begin{array}{l}\text { Male } \\
\text { Female } \\
\text { Total }\end{array}$ & $\begin{array}{c}69 \\
31 \\
100 \\
\end{array}$ & $\begin{array}{c}69.0 \\
31.0 \\
100.0\end{array}$ \\
\hline Marital Status & $\begin{array}{l}\text { Married } \\
\text { Single } \\
\text { Widowed } \\
\text { Never Married } \\
\text { Engaged to be Married } \\
\text { Total }\end{array}$ & $\begin{array}{c}50 \\
44 \\
1 \\
1 \\
4 \\
100\end{array}$ & $\begin{array}{c}50.0 \\
44.0 \\
1.0 \\
1.0 \\
4.0 \\
100.0\end{array}$ \\
\hline Education & $\begin{array}{l}\text { No Education } \\
\text { Primary Education } \\
\text { Secondary Education } \\
\text { Polytechnic Education } \\
\text { Tertiary Education } \\
\text { Total }\end{array}$ & $\begin{array}{c}0 \\
0 \\
12 \\
7 \\
81 \\
100 \\
\end{array}$ & $\begin{array}{c}0.0 \\
0.0 \\
12.0 \\
7.0 \\
81.0 \\
100.0\end{array}$ \\
\hline Occupation & $\begin{array}{l}\text { Farming } \\
\text { Artisan } \\
\text { Trading/Business } \\
\text { Public/Civil Servant } \\
\text { Handicraft Industries } \\
\text { Other } \\
\text { Total }\end{array}$ & $\begin{array}{c}2 \\
1 \\
16 \\
41 \\
0 \\
40 \\
100\end{array}$ & $\begin{array}{c}2.0 \\
1.0 \\
16.0 \\
41.0 \\
0.0 \\
40.0 \\
100.0\end{array}$ \\
\hline
\end{tabular}

Source: Field survey, 2021 
Table-2. Distribution of respondents based on the causes of international migration in Nigeria.

\begin{tabular}{|c|c|c|c|c|c|c|c|c|}
\hline Opinion & $\begin{array}{c}\text { Opinion } \\
\text { Status } \\
\end{array}$ & $\begin{array}{c}\text { Most } \\
\text { Important (X5) } \\
\end{array}$ & $\begin{array}{c}\text { Important } \\
\left(\mathrm{X}_{4}\right)\end{array}$ & $\begin{array}{c}\text { Neutral } \\
(\mathrm{X} 3)\end{array}$ & $\begin{array}{c}\text { Less Important } \\
(\mathrm{X} 2) \\
\end{array}$ & $\begin{array}{c}\text { Least } \\
\text { Important }\left(\mathrm{X}_{1}\right) \\
\end{array}$ & Sum & Mean \\
\hline Job opportunities & Economic & 370 & 84 & 6 & 2 & 2 & 464 & 4.64 \\
\hline Wealth prospects & Economic & 265 & 148 & 27 & 2 & $\mathrm{O}$ & 442 & 4.42 \\
\hline Lack of necessary technology & Economic & 130 & 132 & 60 & 34 & 4 & 360 & 3.60 \\
\hline Poor educational systems & Economic & 125 & 156 & 57 & 22 & 6 & 366 & 3.66 \\
\hline Unemployment & Economic & 380 & 48 & 21 & 8 & 1 & 458 & 4.58 \\
\hline Rural poverty & Economic & 180 & 152 & 51 & 12 & 3 & 398 & 3.98 \\
\hline Unsustainable livelihood & Economic & 160 & 148 & 66 & 18 & $\mathrm{O}$ & 392 & 3.92 \\
\hline An abundance of natural resources & Ecological & 85 & 88 & 54 & 46 & 20 & 293 & 2.93 \\
\hline Favourable climate & Ecological & 75 & 60 & 45 & 52 & 29 & 261 & 2.61 \\
\hline Climate change & Ecological & 35 & 36 & 57 & 54 & 38 & 220 & 2.20 \\
\hline Crop failure/food scarcity & Ecological & 90 & 68 & 60 & 50 & 20 & 288 & 2.88 \\
\hline Family reunification & Sociopolitical & 60 & 60 & 45 & 52 & 32 & 249 & 2.49 \\
\hline Independence and Freedom & Sociopolitical & 115 & 88 & 60 & 46 & 12 & 321 & 3.21 \\
\hline Food security & Sociopolitical & 125 & 140 & 42 & 30 & 11 & 348 & 3.48 \\
\hline Affordable and accessible urban services & Sociopolitical & 115 & 160 & 51 & 24 & 8 & 358 & 3.58 \\
\hline Political instability & Sociopolitical & 110 & 124 & 75 & 30 & 7 & 346 & 3.46 \\
\hline Safety and security & Sociopolitical & 235 & 128 & 42 & 10 & 3 & 417 & 4.17 \\
\hline Conflicts or threats & Sociopolitical & 150 & 124 & 72 & 20 & 5 & 371 & 3.71 \\
\hline Better conditions of services & Economic & 230 & 144 & 24 & 16 & 2 & 416 & 4.16 \\
\hline Slavery or bonded labour & Sociopolitical & 70 & 56 & 78 & 58 & 17 & 279 & 2.79 \\
\hline Inadequate/limited urban services \& infrastructure & Sociopolitical & 135 & 148 & 51 & 26 & 6 & 366 & 3.66 \\
\hline Low salaries & Economic & 215 & 148 & 33 & 14 & 2 & 412 & 4.12 \\
\hline Low per capita income & Economic & 190 & 164 & 24 & 22 & 2 & 402 & 4.02 \\
\hline Lack of progression within a career & Economic & 140 & 140 & 60 & 26 & 4 & 370 & 3.70 \\
\hline Limited chances of self-advancement & Economic & 145 & 128 & 72 & 16 & 7 & 368 & 3.68 \\
\hline Poor conditions of services & Economic & 175 & 168 & 54 & 8 & 1 & 406 & 4.06 \\
\hline Political repression & Sociopolitical & 115 & 124 & 57 & 38 & 8 & 342 & 3.42 \\
\hline Higher standards of living & Economic & 235 & 108 & 51 & 12 & 3 & 409 & 4.09 \\
\hline
\end{tabular}


Table-3. Distribution of respondents based on the consequences of international migration in Nigeria.

\begin{tabular}{|c|c|c|c|c|c|c|c|c|}
\hline Opinion & $\begin{array}{c}\text { Opinion } \\
\text { Status } \\
\end{array}$ & $\begin{array}{c}\text { Most } \\
\text { Important (X5) } \\
\end{array}$ & $\begin{array}{c}\text { Important } \\
\text { (X4) }\end{array}$ & $\begin{array}{c}\text { Neutral } \\
(\mathrm{X} 3)\end{array}$ & $\begin{array}{c}\text { Less Important } \\
(\mathrm{X} 2)\end{array}$ & $\begin{array}{c}\text { Least } \\
\text { Important }\left(\mathrm{X}_{1}\right) \\
\end{array}$ & Sum & Mean \\
\hline Increase in remittances & Economic & 185 & 92 & 66 & 32 & 2 & 377 & 3.77 \\
\hline Urban services and social infrastructure under stress & Social & 110 & 168 & 60 & 26 & 3 & 367 & 3.67 \\
\hline Xenophobia & Social & 145 & 104 & 75 & 28 & 6 & 358 & 3.58 \\
\hline Cultural dilution & Social & 105 & 128 & 81 & 32 & 4 & 350 & 3.50 \\
\hline Stricter immigration norms & Political & 100 & 176 & 51 & 32 & 3 & 362 & 3.62 \\
\hline Cheap \& surplus labour & Economic & 125 & 144 & 69 & 30 & 1 & 369 & 3.69 \\
\hline Closes gaps in skills & Economic & 100 & 144 & 66 & 42 & 1 & 353 & 3.53 \\
\hline Push for inclusive policy-making & Political & 70 & 148 & 96 & 24 & 5 & 343 & 3.43 \\
\hline Integrated development & Political & 160 & 168 & 42 & 20 & 2 & 392 & 3.92 \\
\hline Multi-ethnic society and increased tolerance & Social & 90 & 164 & 81 & 22 & 3 & 360 & 3.60 \\
\hline New services from country of origin & Social & 95 & 136 & 60 & 46 & 4 & 341 & 3.41 \\
\hline
\end{tabular}

Source: Field Survey, 2021 


\section{DATA PRESENTATION, ANALYSIS AND DISCUSSION OF RESULTS}

Table 1 shows the demographic characteristics of the respondents. It disclosed that 11 or $11 \%$ of the respondents were less than 20 years, 32 or $32 \%$ of them were in the age range of $21-30$ years, 30 or $30 \%$ of them were in the age range of $31-40$ years, 17 or $17 \%$ of them were in the age range of $41-50$ years, 8 or $8 \%$ of them were in the range of 51-60 years whereas merely 2 or $2 \%$ of them were in the age range of 61 years and above. In terms of gender, 69 or $69 \%$ were male whereas 31 or $31 \%$ were female. Looking at their marital status, 50 or $50 \%$ of them were married, 44 or $44 \%$ of them were single, 1 or $1 \%$ of them were widowed, 1 or $1 \%$ of them were never married while 4 or $4 \%$ of them were engaged to be married. Regarding their education, 12 or $12 \%$ of them had Secondary Education, 7 or $7 \%$ of them had Polytechnic Education, 81 or $81 \%$ of them had Tertiary Education while none of them had any education and Primary Education respectively. Concerning their occupation, 2 or $2 \%$ of them were Farmers, 1 or $1 \%$ of them were Artisans, 16 or $16 \%$ of them were Traders/Businessmen, 41 or $41 \%$ of them were Public/Civil Servant, none of them was in handicraft industries while 40 or $40 \%$ of them were in other occupations.

Table 2 shows the causes of international migration in Nigeria. Twenty eights push and pull factors were identified and incorporated into the questionnaire and the respondents were requested to specify the choice that matches their view. These pushes and pull factors were gotten as a result of in-depth interviews, extensive literature review and participant observation. A 5 -point Likert type scale from " $5=$ most important" to " $1=$ least important" was employed to measure the level of importance of push and pull factors indicated in the questionnaire. The mean of a five-point rating scale, which is 3.00 was the yardstick for deciding on any opinion. The true limits of real numbers were the basis for deciding on any opinion. Since the average of a five points rating scale tallies with the agreed or possessed opinion, 2.50, the lower limit of 3.00 points was used to ascertain whether respondents agreed based on the various rankings that the item was a cause of international migration in Nigeria. Hence, any view with a mean rating of 2.50 and above was viewed as agreed or possessed. However, views with a mean rating of less than 2.50 were viewed as not agreed or not possessed.

The result showed that job opportunities were the leading cause of international migration in Nigeria. It has the highest frequency of 464 with a mean score of 4.64, this is followed by unemployment, with a mean score of 4.58 , then wealth prospects with a mean score of 4.42 , then safety and security with a mean score of 4.17 , then better conditions of service with a mean score of 4.16, then low salaries with a mean score of 4.12 and higher standards of living with a mean score of 4.09. All the views were rated above a mean score of 3.00. Thus, all the respondents agreed that there were leading causes of international migration in Nigeria. It is instructive to note that except for safety and security that was a sociopolitical factor, all the other leading causes of international migration in Nigeria were economic factors. Hence, people are migrating mainly for economic reasons. This result finds an advocate in Kirwin and Anderson (2018).

In Table 3, a scale was created to ascertain the principal consequences of international migration in Nigeria. The factors were obtained as a result of in-depth interviews, participant observation and extensive review of the literature. The scale range from 5 to 1 , where " $5=$ most important" and " $1=$ least important". The foremost effects of international migration in Nigeria were integrated development with a mean score of 3.92, increase in remittances with a mean score of 3.77 , cheap and surplus labour with a mean score of 3.69 , urban services and social infrastructure under stress with a mean score of 3.67, stricter immigration norms with a mean score of 3.62, multiethnic society and increased tolerance with a mean score of 3.60, Xenophobia with a mean score of 3.58, closes gaps in skills with a mean score of 3.53 and cultural dilution with a mean score of 3.50. All the views were rated above a mean score of 3.00. Hence, all the respondents agreed that there were chief positive and negative consequences of international migration in Nigeria. These consequences were economic, social and political. 


\section{CONCLUSION AND RECOMMENDATIONS}

This study examined the leading causes and consequences of international migration in Nigeria through descriptive research design. It presented an overall picture of the push and pull factors responsible for international migration in Nigeria. The result of the study revealed that the principal causes of international migration in Nigeria were job opportunities, unemployment, wealth prospects, safety and security, better conditions of service, low salaries and higher standards of living. These foremost causes of international migration in Nigeria were mostly economic factors. However, safety and security was the only sociopolitical factor that was among leading causes of international migration in Nigeria. Furthermore, the findings showed that the foremost positive and negative effects of international migration in Nigeria were integrated development, increase in remittances, cheap and surplus labour, urban services and social infrastructure under stress, stricter immigration norms, multi-ethnic society and increased tolerance, Xenophobia, close gaps in skills and cultural dilution. These effects were economic, social and political. In terms of increase in remittances, IOM (2016) stated that "remittance inflows from Nigerians abroad are a potential economic development tool. Nigeria is the largest recipient of remittances in sub-Saharan Africa, receiving nearly 65 per cent of officially recorded remittance flows to the region and 2 per cent of global inflows" (p.91). The following is recommended based on the outcome of this study:

a. The strategies of the government for stemming international migration should address push factors of unemployment, safety and security and low salaries and pull factors such as job opportunities, wealth prospects, better conditions of service and higher standards of living since they are the root causes of international migration;

b. The Federal government, states and non-governmental organizations should target their interventions on other push and pull factors that increase susceptibility to international migration, including limited chances of self-advancement, poor conditions of service, poverty, food security and conflicts;

c. Since international migration are caused by economic, sociopolitical and ecological factors and also affects development at micro and macro levels, policies of migration should not be only restrictive but ponder on how variations in the framework of migration governance affect economic, sociopolitical and environmental matters;

d. Entrepreneurship centres and programmes should be developed by the government and non-governmental organizations to present livelihood choices such as basic education, literacy and skills training to groups that are customarily disadvantaged like women and more susceptible to international migration;

e. Infrastructural development should be among the priority of the government in terms of investment to serve as a stand for the cultivation of skills and acquisition;

f. Migration, a long-standing poverty reduction and strategy for human development needs to be mainstreamed into policies of development in Nigeria at the Federal, State and Local Governments;

g. The government should invest heavily in projects that can generate employment for the teeming unemployed youths in Nigeria to curtail the rate at which they are leaving the country.

h. IOM (2016) advocated that "there is also the need for the integration of migration into national and regional agenda for security, stability, development and cooperation as well as the recognition of migrants' contributions to the world economy because of the obvious far-reaching consequences of migration" (p.94).

Funding: This study received no specific financial support.

Competing Interests: The author declares that there are no conflicts of interests regarding the publication of this paper. 


\section{REFERENCES}

Abedi-Lartey, A. (2016). Causes of rural-urban migration on Sankana in the Nadowli-Kalio District of Ghana and its effects on community development. An Unpublished Bachelor's Degree Thesis in Natural Resource Management of Nonia University of Applied Sciences, Raseborg.

Adebowale, A. (2014). Industrialization, entrepreneurship and the cyclical migration flows between Ghana and Nigeria. Journal of Sustainable Development in Africa, 16(4), 102-114.

Adepoju, A. (2011). Reflections on international migration and development in Sub-Saharan Africa. African Population Studies, 25(2), 298-319.

Ajaero, C. K., \& Onokala, P. C. (2013). The effects of rural-urban migration on rural communities of Southeastern Nigeria. International Journal of Population Research, 1-10. Available at: https://doi.org/10.1155/2013/610193.

Anjofui, P. A. (2018). Investigating the push and pull factors of international migration in South Africa; The case of Cameroonian and Congolese migrants in cape town. An Unpublished Master's Degree Thesis of the Department of ISD, Faculty of Economic and Social Sciences, University of the Western Cape, Bellville.

Bakke, M. (2013). How does religion affect trafficking in Nigerian women? An analysis of the relations between religious beliefs and human trafficking. An Unpublished MA in Anthropology of Health and the Body in the 21st Century Dissertation of the Department of Anthropology, Goldsmiths, University of London.

Bedasso, B., Weldesenbet, E. G., \& Obikili, N. (2018). Emigration and education: the schooling of the left behind in Nigeria. ERSA Working Paper No 759.

Boswell, C. (2002). New issues In refugee research - Addressing the causes of migratory and refugee movements: The role of the European Union. Working Paper No. 73. Institute for Peace Research and Security Policy, University of Hamburg, Germany.

Bukar, H. M., Mohammed, H. I., \& Ngada, B. J. (2021). Causes and consequences of rural-urban migration in Damaturu, Yobe State, Nigeria. International Journal of Management Studies and Social Science Research, 3(3), 282-287.

De Haas, H. (2007). The impact of international migration on social and economic development in Moroccan sending regions: A review of the empirical literature. IMI Working Paper No. 3, International Migration Institute, University of Oxford.

De Haas, H. (2007). The Myth of invasion: Irregular migration from West Africa to the Maghreb and the European Union. Oxford: International Migration Institute, University of Oxford.

Dimkpa, P. (2019). Africa-Europe migration: A qualitative analysis of Nigerian Migration to Europe via the Libya-mediterranean route. An Unpublished Master's Thesis in African Studies of the Dalarna University Centre for African Studies.

Dovlo, D. (2003). The brain drain and retention of health professionals in Africa. Paper presented at the Improving Tertiary Education in Sub-Saharan Africa: Things that Work.

El-Khawas, M. A. (2004). Brain drain: Putting Africa between a rock and a hard place. Mediterranean Quarterly, 15(4), 37-56. Available at: https://doi.org/10.1215/10474552-15-4-37.

Enigbokan, O., Edkins, B., \& Ogundele, O. (2015). Relevance of migration theories in the identification of influencing factors for Nigerian and Zimbabwean migrants in South Africa. Paper presented at the Economic Society of South Africa Conference, Cape Town.

Golden, I., \& Reinert, A. (2006). Globalization for development: Trade, finance, aid, migration, and policy. United States: World Bank Publications.

Harris, J. R., \& Todaro, M. P. (1970). Migration, unemployment and development: A two-sector analysis. American Economic Review, 60(1), 126-142.

Harzig, C., Hoerder, D., \& Gabaccia, D. (2009). What is migration history? Cambridge: Malden, Polity Press.

IOM. (2004). International migration law: Glossary on migration. Geneva: IOM.

IOM. (2016). Migration in Nigeria: A country profile 2014. Geneva: IOM.

Kirwin, M., \& Anderson, J. (2018). Identifying the factors driving West African migration. West African Papers, No.17. Paris: OECD Publishing. 
Lee, E. S. (1966). A theory of migration. Demography, 3(1), 47-57.

Mabogunje, A. L. (1970). Systems approach to a theory of rural-urban migration. Geographical Analysis, 2(1), 1-18.

Massey, D. S. (1990). Social structure, household strategies, and the cumulative causation of migration. Population Index, 56(1), 3-26. Available at: https://doi.org/10.2307/3644186.

McAuliffe, M., \& Khadria, B. (2019). Report overview: Providing perspective on migration and mobility in increasingly uncertain times. In M. McAuliffe \& B. Khadria (Eds.), World Migration Report 2020 (pp. 1-498). Geneva: IOM.

McDowell, C., \& De Haan, A. (1997). Migration and sustainable livelihoods: A critical review of the literature. Institute of Development Studies (IDS) Working Paper NO. 65.

Muhammad, Y. U. (2021). Irregular migration and security challenges in North-Western Nigeria: Trends, issues and the way forward. The International Journal of Social Sciences World, 3(1), 1-14.

National Geographic Society. (2005). Human migration guide. 6-8. Retrieved from: http://geographymonkey.com/uploads/3/5/2/1/35215747/migration nat geo.pdf.

Nkamleu, G. B., \& Fox, L. (2006). Taking stock of research on regional migration in Sub-Saharan Africa. Munich: Personal RePEc Archive.

Nwalutu, M. O. (2016). From Africa to Europe, youth and transnational migration: Examining the lived experiences of Nigerian migrant youth in Malta. An Unpublished Doctor of Philosophy Thesis of the Department of Social Justice Education, OISE, University of Toronto.

Olajide, O. A. (2014). Migration: Its causes and consequences in South-East Nigeria In A. L. Sa (Ed.), African Dynamics in a Multipolar World. Paper presented at the 5th European Conference on African Studies, Lisbon University Institute.

Oludayo, F. M. (2019). A global trend of child trafficking among girls experiencing violence and neglect in the Yoruba ethnic group in Nigeria: A transnational feminist approach. An Unpublished Master of Arts Degree Thesis of Oregon State University.

Oyebanji, K. F. (2017). Human trafficking across a border in Nigeria: Experiences of young women who have survived trafficking. An Unpublished Master of Arts Degree of the Department of Women's and Gender Studies, University of the Western Cape.

Ozuru, G., \& Nwajah, P. O. (2019). Towards a human rights approach for the treatment of migrants in Nigeria. Nnamdi Azikiwe University Journal of International Law and Jurisprudence, 10(1), 91-100.

Piore, M. J. (1979). Birds of passage: Migrant labour and industrial societies. Cambridge: Cambridge University Press.

Ranjana, D. (2015). Human trafficking: A study exploring its causes, current efforts and challenges. An Unpublished Master's Degree in Development Studies of the Department of Humanities and Social Sciences, National Institute of Technology Rourkela, Odisha, India.

Ratha, D., Mohapatra, S., \& Scheja, E. (2011). Impact of migration on economic and social development: A review of evidence and emerging issues. Policy Research Working Paper No. 5558.

Rohrmoser, F., \& Wachter, M. (2008). Migration at the Southern borders of the European Union:“The EUs migration policy towards the Mediterranean and the case of Spain.

Skeldon, R. (1990). Population mobility in developing countries: A reinterpretation. London: Belhaven Press.

Stark, O. (1978). Economic-demographic interactions in agricultural development: The case of rural-to-urban migration. Rome: FAO.

Stark, O. (1991). The migration of labour. Blackwell: Cambridge and Oxford.

Todaro, M. P., \& Smith, S. (2006). Economic development. Boston: Addison Wesley.

Wajim, J. (2019). Labour migration: Causes and patterns in Nigeria. International Journal of Research and Innovation in Social Science, 3(10), 116-123.

Weda, Z. L. (2012). Factors influencing the migration of teachers from Zimbabwe to South Africa. An Unpublished Doctor of Education Degree Thesis in Socio-Education of the University of South Africa.

Weiner, M. (1995). The global migration crisis: Challenges to states and to human rights. New York: Harper Collins.

World Economic Forum \& PwC. (2017). Migration and its impact on cities. Retrieved from: http://www3.weforum.org/docs/Migration_Impact_Cities_report_2017_low.pdf. 
Yang, D. (2008). International migration, remittances and household investment: Evidence from Philippine migrants' exchange rate shocks. The Economic Journal, 118(528), 591-630. Available at: https://doi.org/10.1111/j.1468-0297.2008.02134.x.

Zelinsky, W. (1971). The hypothesis of the mobility transition. Geographical Review, 61(2), 219-249. Available at: https://doi.org/10.2307/213996.

Views and opinions expressed in this article are the views and opinions of the author(s), Asian Development Policy Review shall not be responsible or answerable for any loss, damage or liability etc. caused in relation to/arising out of the use of the content. 